\title{
Perbandingan Ketebalan Retina Sentral Pasien Hipertensi Esensial tanpa Penurunan Visus Dibanding Orang Normal
}

\author{
${ }^{1}$ Ade J. Nursalim \\ ${ }^{2}$ Vera Sumual \\ ${ }^{2}$ Eugeni Sumanti
}

\author{
${ }^{1}$ PPDS Ilmu Kesehatan Mata Fakultas Kedokteran Universitas Sam Ratulangi Manado \\ ${ }^{2}$ Divisi Vitreoretina Bagian Ilmu Kesehatan Mata Universitas Sam Ratulangi/ \\ RSUP Prof. Dr. R. D. Kandou Manado. \\ Email: dr.adejn@gmail.com
}

\begin{abstract}
One of the complications of hypertension is hypertensive retinopathy with a prevalence of $2-17 \%$ in patients with hypertension without diabetes. Application of optical coherence tomography (OCT) tool enables the clinician to simplify the pathophysiological process of hypertensive retinopathy. This study was aimed to compare the central retina thickness of essential hypertensive patients without decreased vision to of normal people. This was a prospective comparative study using a quantitative method. There were 56 eyes in the hypertension group and 71 eyes in the normal group. The t test showed that central retina thickness in hypertension group was $201.66 \mu \mathrm{m}(\mathrm{SD} \pm 38,870)$ meanwhile in the normal group was $249.59 \mu \mathrm{m}(\mathrm{SD} \pm 19,245)(\mathrm{p}=0.004)$. In conclusion, there was a significant difference in central retinal thickness between essential hypertensive patients and normal people. It is suggested that ophthalmologic examination should be performed on patients with essential hypertension even without decreased vision.
\end{abstract}

Keywords: hypertension, decrease of vision, retinal thickness

\begin{abstract}
Abstrak: Salah satu komplikasi hipertensi yaitu retinopati hipertensi dengan prevalensi 2-17\% pada penyandang hipertensi tanpa diabetes. Aplikasi alat optical coherence tomography (OCT) memungkinkan klinisi untuk meneliti lebih lanjut mengenai proses patofisiologi retinopati hipertensi. Penelitian ini bertujuan untuk membandingkan ketebalan retina sentral pasien hipertensi esensial tanpa penurunan visus dibanding orang normal. Jenis penelitian ialah prospektif komparatif menggunakan metode kuantitatif. Hasil penelitian mendapatkan 56 mata untuk kelompok hipertensi dan 71 mata untuk kelompok normal yang memenuhi kriteria penelitian. Uji t menunjukkan terdapat perbedaan ketebalan retina sentral pada kelompok hipertensi dibanding kelompok normal. Rerata ketebalan retina pada kelompok hipertensi ialah 201,66 $\mu \mathrm{m}(\mathrm{SD} \pm 38,870)$ dibanding pada kelompok normal ialah 249,59 $\mu \mathrm{m}$ $(\mathrm{SD} \pm 19,245)(\mathrm{p}=0,004)$. Simpulan penelitian ini ialah terdapat perbedaan bermakna antara ketebalan retina sentral pasien hipertensi esensial tanpa penurunan visus dibanding orang normal. Disarankan untuk melakukan pemeriksaan mata pada penyandang hipertensi esensial meskipun belum disertai keluhan penurunan tajam penglihatan.
\end{abstract}

Kata kunci: hipertensi, penurunan visus, ketebalan retina

Sebuah laporan pada Journal of the American Society of Hypertension tahun 2016 menu-liskan prevalensi hipertensi melebihi 1,3 milliar. Penulis menyatakan bahwa prevalensi hipertensi mencapai 1,39 juta orang yang merupakan $31 \%$ dari seluruh penduduk dunia. Prevalensi ini lebih tinggi dibandingkan dengan data dari Framingham Heart study, salah satu penelitian epidemiologi awal dalam bidang 
hipertensi yang menunjukkan bahwa dari 4469 pasien acak yang diukur tekanan darahnya sejak tahun 1949 hingga 1952 terdapat $18 \%$ populasi tersebut yang meng-alami hipertensi. ${ }^{1,2}$ Prevalensi antara tahun 2000 dan tahun 2010 pun mengalami peningkatan sebanyak 5,2\%. Data ini juga menunjukkan disparitas antara negara dengan penghasilan tinggi dibanding negara dengan penghasilan rendah dimana didapatkan peningkatan $2,6 \%$ pada negara dengan peng-hasilan tinggi. ${ }^{2}$ Laporan oleh Zhou et $\mathrm{al}^{3}$ tahun 2017 menunjukkan terjadinya penurunan rerata tekanan darah pada negara barat berpenghasilan tinggi dan negara Asia Pasifik tetapi pada Asia Timur, Asia Tenggara, Asia Selatan, Oceania dan Afrika Sub-Sahara, terjadi peningkatan rerata tekanan darah dibanding tahun sebelumnya. Peningkatan rerata tekanan darah pun terjadi pada negara berpenghasilan rendah seperti Asia Timur dan Afrika Sub Sahara. Peningkatan tekanan darah di dunia lebih banyak di alami oleh jenis kelamin laki-laki daripada perempuan yaitu mencapai $24,1 \%$ untuk laki-laki dibanding 20,1\% untuk perempuan pada tahun 2015 .

Hipertensi merupakan salah satu penyebab kematian utama di dunia. Salah satu kelainan patologik yang mendasari kerusakan yang disebabkan oleh hipertensi ialah disfungsi endotel. Istilah disfungsi endotel merujuk kepada abnormalitas pada kapasitas vasodilatasi dari pembuluh darah. Kerusakan ini juga mendasari kelainan patologik yang terjadi pada salah satu komplikasi hipertensi yaitu retinopati hipertensi. ${ }^{4}$

Retinopati hipertensi memiliki prevalensi $2-17 \%$ pada pasien dengan hipertensi tanpa diabetes. Prevalensi pada laki-laki lebih tinggi dibanding perempuan $(34,1 \%$ vs $32,7 \%$ ). Retinopati hipertensi juga memiliki prevalensi yang lebih tinggi pada usia 75 tahun ke atas dibanding dengan usia yang lebih muda, dan paling banyak diderita oleh ras Afrika Amerika. ${ }^{5}$

Retinopati hipertensi dapat diklasifikasikan berdasarkan 4 grade menurut Keith, Wagener dan Barker (1939). Grade 0 tidak menunjukkan kelainan apapun dan grade 1 diawali dengan pelebaran arteri dan sklerosis ringan pada pembuluh darah dengan tahap tertinggi pada grade 4 dengan pelebaran arteri, penyilangan arteri vena yang berat dengan perdarahan, eksudat dan cotton wool spot disertai pembengkakan saraf optik. ${ }^{6}$ Pada tahun 2004, Mitchell-Wong ${ }^{7}$ mengusulkan sistem klasifikasi baru dengan mempertimbangkan implikasi klinis pada penderita retinopati hipertensi. Mitchell-Wong membagi tingkat keparahan dimulai dengan grade none yang menunjukkan tidak adanya tanda yang terdeteksi hingga grade malignant yang menunjukkan perdarahan blot dot atau flame shaped, mikroaneurisma, cotton wool spot, dan hard exudation. Selain itu, Mitchell-Wong menghubungkan grade malignant retinopati hipertensi dengan kematian.

Patofisiologi retinopati hipertensi berawal dari peningkatan tekanan darah baik akut maupun kronik yang bisa terjadi karena hipertensi esensial ataupun hipertensi sekunder. Peningkatan ini meningkatkan tekanan luminal yang direspon oleh tubuh berupa vasospasme dan vasokonstriksi. Fase ini disebut sebagai fase vasokonstriksi yang terlihat sebagai pelebaran pembuluh darah arteri retina pada pemeriksaan funduskopi. Seiring dengan berjalannya waktu, peningkatan tekanan darah ini mengakibatkan kerusakan endotel dengan penebalan tunika intima pembuluh darah dan pelebaran pembuluh darah yang mengakibatkan sklerosis, terlihat sebagai gambaran opak pada dinding arteri atau yang dikenal sebagai copper wiring dengan penekanan arteri ke vena yang disebabkan oleh tekanan dari arteri yang menebal pada vena. Keadaan ini dapat terjadi terus hingga terjadi kebocoran materi plasma dan berakhir pada edema saraf optik. ${ }^{5}$

Aplikasi alat optical coherence tomography (OCT) dalam dunia kedokteran mata memungkinkan klinisi untuk meneliti lebih lanjut mengenai proses patofisiologi retinopati hipertensi yang pada tahun 1939 ketika sistem grading retinopati hipertensi masih belum ditentu- 
kan. Sebuah penelitian dari Wei et al $^{8}$ pada tahun 2013 menunjukkan peningkatan ketebalan koroid subfoveal pada pasien dengan hipertensi. Zhang et $\mathrm{al}^{9}$ pada tahun 2012 juga telah meneliti kerusakan retinal nerve fiber layer (RNFL) setelah terbentuknya cotton wool spots sebagai konsekuensi retinopati hipertensi pada retina.

Penelitian ini bertujuan untuk membandingkan ketebalan retina sentral pasien hipertensi esensial tanpa penurunan visus dengan orang normal.

\section{METODE PENELITIAN}

Penelitian ini merupakan studi kasus kontrol. Jenis penelitian ialah prospektif komparatif yang membandingkan ketebalan retina sentral pasien hipertensi esensial tanpa penurunan visus dengan orang normal. Penelitian dilakukan sejak bulan Juni hingga Juli 2019. Kriteria inklusi untuk penelitian ini ialah pasien dengan hipertensi esensial tanpa penurunan visus dan orang normal dengan tekanan darah dalam batas normal dan tidak memiliki riwayat penyakit sistemik lainnya yang berobat ke poliklinik rawat jalan Ilmu Kesehatan Mata Rumah Sakit Khusus Mata, Provinsi Sulawesi Utara, visus 6/6, serta media refraksi jernih yang memungkinkan dilakukannya funduskopi dan OCT. Kriteria eksklusi ialah pasien dengan diagnosis penyakit mata selain retinopati hipertensi, pasca operasi di area vitreoretina, dan pasca tindakan laser photocoagulation.

Pasien yang datang dikelompokkan ke dalam dua kelompok yaitu kelompok hipertensi dan kelompok normal. Pada kedua kelompok dilakukan pemeriksaan ketebalan retina sentral dengan alat OCT. Hasil pemeriksaan diolah dengan menggunakan komputer. Analisis univariat digunakan untuk melaporkan distribusi frekuensi data penelitian dan analisis bivariat dalam bentuk uji $\mathrm{t}$ independen untuk menganalisis signifikansi perbedaan rerata ketebalan retina sentral antar kedua kelompok.

Penelitian ini telah mendapatkan persetujuan etik dari Komisi Etik Penelitian
Kesehatan (KEPK) Rumah Sakit Umum Pusat Prof. Dr. R. D. Kandou, Manado dengan nomor surat 071/EC-KEPK/ $\mathrm{VI} / 2019$.

\section{HASIL PENELITIAN}

Penelitian ini dilakukan di Rumah Sakit Mata Provinsi Sulawesi Utara. Subjek penelitian sebanyak 56 mata untuk kelompok hipertensi dan 71 mata untuk kelompok normal yang memenuhi kriteria penelitian. Tiap kelompok penelitian diberikan perlakuan sesuai konsep penelitian yaitu setiap subjek diberikan informed consent dan kemudian dilakukan pemeriksaan OCT.

Hasil penelitian menunjukkan kedua kelompok didominasi oleh jenis kelamin perempuan. Pada kelompok hipertensi terdapat sebanyak 31 orang $(55,4 \%)$ perempuan dan 25 orang $(44,6 \%)$ laki-laki sedangkan pada kelompok normal terdapat sebanyak 36 orang $(50,7 \%)$ perempuan dan 35 orang $(49,3 \%)$ laki-laki.

Usia minimum pada kelompok hipertensi ialah 29 tahun dan usia maksimum pada kelompok hipertensi ialah 80 tahun. Nilai median usia ialah 53 tahun dan nilai rerata usia ialah 52,23 tahun $(\mathrm{SD} \pm 12,140)$. Usia minimum pada kelompok normal ialah 11 tahun dan usia maksimum pada kelompok hipertensi ialah usia 74 tahun. Nilai median usia ialah 55 tahun dan nilai rerata usia ialah 51,23 tahun $(\mathrm{SD} \pm 12,559)$. Rerata tekanan darah sistolik untuk kelompok hipertensi ialah 153,21 mmHg (SD $\pm 9,714)$. Rerata tekanan darah diastolik pada kelompok hipertensi ialah 99,93 $\mathrm{mmHg}(\mathrm{SD} \pm 5,746)$. Rerata ketebalan retina pada kelompok hipertensi ialah 201,66 $\mathrm{mmHg}(\mathrm{SD} \pm 38,870)$, rerata durasi hipertensi pada kelompok hipertensi ialah 10 tahun $(\mathrm{SD} \pm 8,451)$. Rerata tekanan darah sistolik untuk kelompok normal ialah $126,93 \mathrm{mmHg}(\mathrm{SD} \pm 6,216)$. Rerata tekanan darah diastolik pada kelompok normal ialah $84 \mathrm{mmHg}(\mathrm{SD} \pm 3,265)$. Rerata ketebalan retina pada kelompok normal ialah 249,59 $\mu \mathrm{m}(\mathrm{SD} \pm 19,245)$.

Hasil uji statistik KolmogorovSmirnov menunjukkan data hasil penelitian 
memiliki penyebaran normal. Uji statistik dilanjutkan dengan uji $t$ independen untuk membandingkan rerata kedua kelompok dan didapatkan signifikansi 0,004 yang menunjukkan rerata ketebalan retina pada kelompok hipertensi yaitu 201,66 $\mu \mathrm{m}$ $(\mathrm{SD} \pm 38,870)$ lebih rendah daripada kelompok normal yaitu $249,59 \mu \mathrm{m}(\mathrm{SD} \pm 19,245)$.

\section{BAHASAN}

Penelitian ini berhasil mengumpulkan subyek sesuai kriteria penelitian sebanyak 56 mata untuk kelompok hipertensi dan 71 mata untuk kelompok normal. Kelompok hipertensi didominasi oleh jenis kelamin perempuan yaitu sebanyak 31 orang $(55,4 \%)$ sedangkan jenis kelamin laki-laki sebanyak 25 orang $(44,6 \%)$. Hipertensi merupakan faktor risiko berbagai macam penyakit kronis dan menjadi beban morbidditas dan mortalitas global. Proporsi hipertensi untuk laki-laki dan perempuan secara umum berbeda dengan hasil penelitian ini. Proporsi hipertensi di beberapa negara didominasi oleh laki-laki. India memiliki angka hipertensi pada laki-laki lebih tinggi daripada perempuan yaitu 13,8\% pada laki-laki dibandingkan $8,8 \%$ pada perem-puan. ${ }^{10}$ Proporsi ini berubah ketika perempuan memasuki masa menopause. Defisiensi esterogen dan progestin meningkatkan risiko hipertensi pada perempuan. Hal ini terjadi rata-rata setelah usia 70 tahun ke atas. Hal ini juga berlaku pada pasien yang telah melalui prosedur ovariektomi. ${ }^{11}$ India dan Indonesia memiliki profil yang sama sebagai negara dengan kategori penghasilan rendah dan menengah. Prevalensi hipertensi lebih tinggi pada negara dengan penghasilan rendah dan menengah yaitu $31,5 \%$ dibanding negara dengan penghasilan tinggi yang mencapai $28,5 \%$. $^{12,13}$

Hasil penelitian Riset Kesehatan Dasar Negara Republik Indonesia (RISKESDAS) 2018 tidak membagi penderita hipertensi berdasarkan jenis kelamin akan tetapi, Provinsi Sulawesi Utara, tempat dilaksanakannya penelitian ini menduduki peringkat pertama jumlah penduduk hipertensi berdasarkan diagnosis dokter. Prevalensi ini berada di angka 13,2\% dari keseluruhan penduduk, yang jauh berada di atas rerata nasional yang berada pada $8,4 \%{ }^{14}$ Obesitas, ${ }^{15,16}$ minum minuman beralkohol secara berlebihan, ${ }^{17,18}$ dan merokok ${ }^{19,20}$ diketahui merupakan faktor risiko terjadinya hipertensi. Provinsi Sulawesi Utara menduduki posisi pertama nasional untuk obesitas yang mencapai $30,2 \%$ dari keseluruhan penduduk dibanding rerata nasional yang mencapai $21,8 \%$. Selain itu, Provinsi Sulawesi Utara juga memiliki angka proporsi konsumsi minuman beralkohol pada penduduk dengan usia lebih dari 10 tahun yaitu mencapai angka $16 \%$ yaitu sekitar 5 kali lipat lebih tinggi daripada proporsi nasional yang hanya 3,3\%. Proporsi konsumsi tembakau nasional cenderung stabil di angka 34,3 pada tahun 2007 hingga 33,8 di tahun 2018. ${ }^{13}$

Hasil penelitian ini menunjukkan usia minimum pada kelompok hipertensi ialah 29 tahun. Hasil penelitian epidemiologi di India menunjukkan usia minimal hipertensi yang dilaporkan oleh Gupta et al $^{10}$ ialah 15 tahun, akan tetapi, American Academy of Pediatric (AAP) dalam laporannya tahun 2018 tidak membatasi usia minimum penyandang hipertensi. Menurut AAP, hipertensi pada anak bisa terjadi pada usia 0-18 tahun. ${ }^{12}$

Rerata ketebalan retina pada kelompok hipertensi ialah 201,66 (SD $\pm 38,870)$, rerata durasi hipertensi pada kelompok hipertensi ialah 10 tahun $(\mathrm{SD} \pm 8,451)$. Lee et $\mathrm{al}^{21}$ mendapatkan ketebalan retina sentral pada kelompok hipertensi ialah 245,08 $\mu \mathrm{m}$ $(\mathrm{SD} \pm 10,79)$. Penelitian lain oleh Lee et $\mathrm{al}^{22}$ dalan sebuah studi longitudinal di Korea mendapatkan rerata ketebalan dari 18 sampel mata berada pada $233,8 \mu \mathrm{m}$ $(\mathrm{SD} \pm 30,8) .{ }^{23}$ Rerata ketebalan retina pada kelompok normal ialah 249,59 $\mu \mathrm{m}$ $(\mathrm{SD} \pm 19,245)$. Penelitian yang sama dengan menggunakan 18 sampel mata melaporkan ketebalan retina pada kelompok normal ialah 256,3 $\mu \mathrm{m}(\mathrm{SD} \pm 28,1)$. Chan et $\mathrm{al}^{23}$ mengukur ketebalan makula orang normal pada 37 mata sehat dan mendapatkan ketebalan retina sentral pada orang normal ialah $212 \mu \mathrm{m} \quad(\mathrm{SD} \pm 20)$. Penelitian di 
Bulgaria yang melibatkan 163 mata sehat melaporkan ketebalan retina sentral mencapai 248,9 $\mu \mathrm{m}(\mathrm{SD} \pm 17,9){ }^{24}$

Perbedaan ketebalan retina sentral yang didapatkan pada penelitian ini dan penelitian lainnya kemungkinan disebabkan oleh faktor perbedaan etnis. Hal yang serupa pernah dilaporkan oleh Kelty et $\mathrm{al}^{25}$ pada tahun 2008 yang meneliti ketebalan retina pada ras Kaukasian dan membandingkannya dengan ras Afrika Amerika. Kelty et al mendapatkan bahwa fovea pada ras Kaukasia cenderung lebih tebal daripada ras Afrika Amerika. Perbedaan ketebalan antara jenis kelamin juga dilaporkan oleh penelitian yang sama yaitu jenis kelamin perempuan cenderung memiliki ketebalan retina yang lebih tebal daripada laki-laki.

Uji statistik dengan uji t menunjukkan signifikansi 0,004 dengan rerata ketebalan retina pada kelompok hipertensi ialah 201,66 $\mu \mathrm{m}$ (SD $\pm 38,870)$, lebih rendah daripada kelompok normal 249,59 $\mu \mathrm{m}$ $(\mathrm{SD} \pm 19,245)$. Temuan ini didukung oleh beberapa penelitian yang melaporkan hal serupa. Hasil penelitian oleh Lee et $\mathrm{al}^{22}$ di Korea mendapatkan penurunan ketebalan retina pada pasien hipertensi dibandingkan pasien normal yaitu $233,8 \mu \mathrm{m}(\mathrm{SD} \pm 30,8)$ pada pasien hipertensi dibanding $256,3 \mu \mathrm{m}$ $(\mathrm{SD} \pm 28,1)$ pada pasien normal.

\section{SIMPULAN}

Berdasarkan hasil penelitian ini dapat disimpulkan bahwa terdapat perbedaan bermakna antara ketebalan retina sentral pasien hipertensi esensial tanpa penurunan visus dibanding orang normal. Disarankan untuk melakukan pemeriksaan mata pada penyandang hipertensi esensial meskipun belum disertai keluhan penurunan tajam penglihatan.

\section{DAFTAR PUSTAKA}

1. Bloch MJ. Worldwide prevalence of hypertension exceeds 1.3 billion. J Am Soc Hypertens. 2016;10(10):753-4. doi:10.1016/j.jash.2016.08.006

2. Rahimi K, Emdin CA, MacMahon S. The epidemiology of blood pressure and its worldwide management. Circulation Res. 2015;116(6):925-36.

3. Zhou B, Bentham J, Di Cesare M, Bixby H, Danaei G, Cowan MJ, et al. Worldwide trends in blood pressure from 1975 to 2015: a pooled analysis of 1479 population-based measurement studies with 19. 1 million participants. Lancet. 2017; 389(10064):37-55.

4. Mordi I, Mordi N, Delles C, Tzemos N. Endothelial dysfunction in human essential hypertension. J Hypertens. 2016; 34(8):1464-72.

5. Harjasouliha A, Raiji V, Garcia Gonzalez JM. Review of hypertensive retinopathy. Dis Mon. 2017; 63(3):63-9.

6. Bokman CL, Gonzalez MA. Hypertensive Retinopathy in Manual of Retinal Diseases. Cham: Springer, 2016; p. 627-9.

7. Wong TY, Mitchell P. Hypertensive retinopathy. N Engl J Med. 2004; 351(22):2310-17.

8. Wei WB, Xu L, Jonas JB, Shao L, Du KF, Wang S, et al. Subfoveal choroidal thickness: The Beijing eye study. Ophthalmology. 2013;120(1):175-80.

9. Zhang L, Xu L, Zhang JS, Zhang YQ, Yang H, Jonas JB. (2012). cotton-wool spot and optical coherence tomography of a retinal nerve fiber layer defect. Arch Ophthalmol. 2012;130(7):913.

10. Gupta R, Gaur K, Ram CV. Emerging trends in hypertension epidemiology in India. J Hum Hypertens. 2018;Sep 25:1.

11. Blacher J, Kretz S, Sorbets E, Lelong H, Vallée A, Lopez-Sublet $M$. Épidémiologie de l'HTA: différences femme/homme. La Presse Médicale. 2019; May 28.

12. Mills KT, Bundy JD, Kelly TN, Reed JE, Kearney PM, Reynolds $K$, et al. Global disparities of hypertension prevalence and control: a systematic analysis of population-based studies from 90 countries. Circulation. 2016; 134(6):441-50.

13. Reynolds K, Chen J, He J. Global disparities of hypertension prevalence and control. Circulation. 2016; 2016 (134):441-50.

14. Kesehatan K, Penelitian B, Kesehatan $P$. Hasil Utama RISKESDAS 2018. Jakarta [ID]: Balitbangkes Kementerian Kesehatan, 2018; p. 61-75. 
15. Jiang SZ, Lu W, Zong XF, Ruan HY, Liu Y. Obesity and hypertension. Experimental and therapeutic medicine. 2016;12(4):2395-9.

16. Seravalle G, Grassi G. Obesity and hypertension. Pharmacol Res. 2017;122:1-7.

17. Rehm J, Prieto JA, Beier M, Duhot D, Rossi A, Schulte B, et al. The role of alcohol in the management of hypertension in patients in European primary health care practices-a survey in the largest European Union countries. BMC family practice. 2016; 17(1):130.

18. Fernandez-Sola J. Cardiovascular risks and benefits of moderate and heavy alcohol consumption. Nat Rev Cardiol. 2015; 12(10):576.

19. Leone A. Smoking and hypertension. J Cardiol Curr Res. 2015;2(2):00057.

20. Li G, Wang H, Wang K, Wang W, Dong F, Qian Y, et al. The association between smoking and blood pressure in men: a cross-sectional study. BMC Public Health. 2017;17(1):797.

21. Lee S H, Lee WH, Lim HB, Jo YJ, Kim JY. Thicknesses of central macular, retinal nerve fiber, and ganglion cell inner plexiform layers in patients with hypertension. Retina. 2018 May 11. doi: 10.1097/IAE. 000000000000 2216. [Epub ahead of print]

22. Lee HM, Lee WH, Kim KN, Jo YJ, Kim JY. Changes in thickness of central macula and retinal nerve fibre layer in severe hypertensive retinopathy: a 1-year longitudinal study. Acta Ophthalmol. 2018;96(3):e386-92.

23. Chan A, Duker JS, Ko TH, Fujimoto JG, Schuman JS. Normal macular thickness measurements in healthy eyes using Stratus optical coherence tomography. Arch Ophthalmol. 2006; 124(2):193-8.

24. Mitkova-Hristova VT, KonarevaKostyaneva MI. Macular thickness measurements in healthy eyes using spectral optical coherence tomography. Folia Medica. 2011;53(4):28-33.

25. Kelty PJ, Payne JF, Trivedi RH, Kelty J, Bowie EM, Burger BM. Macular thickness assessment in healthy eyes based on ethnicity using Stratus OCT optical coherence tomography. Invest Ophthalmol Vis Sci. 2008;49(6):266872. 